\begin{tabular}{|c|c|}
\hline 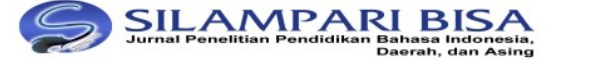 & $\begin{array}{l}\text { PRINTED ISSN: } 2620-6919 \\
\text { ONLINE ISSN: } 2620-3316\end{array}$ \\
\hline $\begin{array}{l}\text { Published by LP4MK STKIP PGRI LUBUKLINGGAU } \\
\text { Prodi Pendidikan Bahasa Indonesia, STKIP PGRI Lubuklinggau, } \\
\text { South Sumatera, Indonesia }\end{array}$ & $\begin{array}{r}\text { Vol. 3, No. 2, } 2020 \\
\text { Page: } 406-427\end{array}$ \\
\hline
\end{tabular}

\title{
PEMBELAJARAN DARING DOSEN NATIVE TIONGKOK TERHADAP MAHASISWA FKIP UNIVERSITAS TANJUNGPURA
}

\author{
Lily Thamrin \\ Fakultas Keguruan dan IImu Pendidikan, Universitas Tanjungpura \\ Jalan Prof H.Hadari Nawawi, Indonesia \\ Email: lily.thamrin@fkip.untan.ac.id
}

\begin{abstract}
Abstrak
Pembelajaran daring di masa pandemi Covid-19 ini menjadi sebuah solusi pengganti pembelajaran tatap muka. Untuk itu, tujuan penelitian ini mendeskripsikan proses pembelajaran daring, masalah-masalah dalam pembelajaran daring, dan strategi pembelajaran daring yang diterapkan pada Mata Kuliah Bahasa Mandarin Komprehensif. Metode penelitian ini menggunakan metode campuran. Teknik pengumpulan data menggunakan teknik pengamatan, kuesioner, dan wawancara. Adapun responden penelitian ini sebanyak 90 orang yang terdiri dari mahasiswa semester satu, tiga, dan lima Program Studi Pendidikan Bahasa Mandarin, Fakultas Keguruan dan IImu Pendidikan, Universitas Tanjungpura, dan 4 orang dosen native yang berasal dari Tiongkok. Hasil penelitian menunjukkan bahwa dosen native dalam proses pembelajaran daring menggunakan aplikasi DingTalk dan Tencent (VooV) Meeting. Media pembelajaran yang digunakan seperti komputer, laptop, maupun smartphone serta jaringan internet telah tersedia namun tidak sepenuhnya digunakan dengan maksimal pada proses pembelajaran daring. Sedangkan kendala yang dihadapi selama pembelajaran daring berlangsung adalah masalah jaringan yang digunakan oleh mahasiswa. Jaringan yang digunakan oleh mahasiswa untuk mengikuti pembelajaran daring sangat tidak stabil, mengakibatkan mahasiswa sering keluar masuk di dalam platform pembelajaran daring ini. Untuk mengatasi permasalahan yang terjadi, dosen sering menggunakan strategi tanya jawab untuk mendapatkan timbal-balik dari mahasiswa. Ada pula dosen yang menggunakan waktu luang untuk membimbing secara tersendiri mahasiswa yang dianggap kurang dalam pembelajaran.
\end{abstract}

Kata kunci: pembelajaran daring, DingTalk, Tencent Meeting, dosen native Tiongkok, bahasa Mandarin

\section{ONLINE LEARNING OF NATIVE TIONGKOK LECTURERS FOR FKIP UNIVERSITAS TANJUNGPURA STUDENTS'}

\begin{abstract}
Online learning during the Covid-19 pandemic has become a substitute solution for face-toface learning. For this reason, the purpose of this study is to describe the online learning process, problems in online learning, and online learning strategies that are applied to Comprehensive Chinese Language Courses. This research method using mixed methods. Data collection techniques using observation techniques, questionnaires, and interviews. The respondents of this study were 90 people consisting of first, third, and five semester students of the Mandarin Education Study Program, the Teaching and Education Faculty, Universitas Tanjungpura, and 4 native lecturers from China. The results showed that native lecturers in the online learning process used the DingTalk and Tencent (VooV) Meeting
\end{abstract}


applications. Learning media used such as computers, laptops, and smartphones as well as internet networks are available but are not fully utilized in the online learning process. Meanwhile, the obstacles faced during online learning are the network problems used by students. The network used by students to take part in online learning is very unstable, resulting in students often going in and out of this online learning platform. To solve the problems that occur, lecturers often use a question and answer strategy to get feedback from students. There are also lecturers who use their spare time to individually guide students who are deemed lacking in learning.

Keywords: online learning, DingTalk, Tencent Meeting, Tiongkok native lecturers, Mandarin

\section{A. Pendahuluan}

Dalam pembelajaran bahasa Mandarin, pembelajaran tatap muka secara langsung akan memberikan hasil yang lebih maksimal dibandingkan dengan pembelajaran daring. Hal ini diungkapkan oleh Wulandari \& Purwanta (2020) bahwa pembelajaran yang dilakukan dengan tatap muka secara langsung dapat memberikan dampak positif pada aspek kognitif dan aspek sosial emosional, yang akan memberikan dampak positif pada kemampuan berbahasa. Dalam pembelajaran bahasa, mahasiswa harus menguasai empat keterampilan dalam berbahasa, yaitu (1) keterampilan menyimak atau mendengarkan, keterampilan berbicara, (3) keterampilan menulis, dan (4) keterampilan membaca (Wijaya, 2018). Gaya belajar memiliki pengaruh terhadap hasil belajar mahasiswa. Mahasiswa akan memperoleh hasil belajar yang baik apabila mahasiswa dapat memahami konsep pelajaran dengan baik (Putrayasa dkk., 2014 dalam Chan \& Rahman, 2019).

Kondisi Covid-19 yang semakin meluas mengharuskan proses kegiatan belajar mengajar sementara waktu dilakukan di rumah. Kebijakan ini dilakukan oleh pemerintah untuk memutus mata rantai penyebaran virus corona tersebut. Proses pembelajaran dilakukan jarak jauh atau daring (dalam jaringan), baik menggunakan ponsel, PC maupun laptop. Pembelajaran daring adalah salah strategi pembelajaran online atau dilakukan melalui jaringan internet (Mustofa dkk., 2019). Kebijakan pembelajaran daring ini tertuang dalam Peraturan Pemerintah Nomor 4 Tahun 2020 tentang Pelaksanaan Kebijakan Pendidikan dalam Masa Darurat Penyebaran Coronavirus Disease (Covid-19). Berbagai upaya dan solusi yang dilakukan oleh Kementerian Pendidikan dan Kebudayaan agar pembelajaran tetap berlangsung dengan mengajak seluruh yang terlibat di 
bidang pendidikan untuk berpartisipasi mengimplentasikan pembelajaran daring di lapangan dengan menuntut kesiapan bagi kedua belah pihak yaitu baik itu pihak penyedia layanan pendidikan maupun dari peserta didik sendiri. Bagaimanapun juga pembelajaran daring memerlukan bantuan teknologi yang dapat di akses dengan mudah. Selain itu, para murid juga mesti beradaptasi dengan perubahan pembelajaran yang diatur oleh sekolah dapat dipandang lebih bebas dan fleksibel diakses dari rumah.

Supriadi dkk. (2019) mengatakan bahwa pembelajaran bahasa asing merupakan salah satu upaya untuk dapat mengikuti perkembangan ilmu pengetahuan dan teknologi di dunia. Selain itu juga sebagai alat yang menjembatani seseorang agar bisa masuk ke dalam masyarakat global. Perkembangan teknologi informasi dan komuniskasi khususnnya di dunia pendidikan telah memberikan pengaruh yang besar terhadap proses pengajaran dan pembelajaran.

Meski tidak dapat bertatap muka, dosen harus berpikir keras agar pembelajaran yang disampaikan tetap dapat menarik minat mahasiswa mengikutinya (Annur \& Hermansyah, 2020). Media daring dirasa sangat efektif sebagai langkah solutif untuk mencegah penyebaran Covid-19 di lingkungan pendidikan. Seiring dengan kebijakan yang mengharuskan pembelajaran melalui daring sehingga bukan hanya mempengaruhi minat mahasiswa untuk belajar saja, melainkan juga berpengaruh pada tuntutan kompetensi para pendidik terutama dalam penggunaan metode dan media pembelajaran (Rusdiana dkk., 2020).

Pembelajaran daring merupakan sebuah inovasi pendidikan yang melibatkan unsur teknologi informasi dalam pembelajaran (Fitriyani dkk., 2020). Pembelajaran yang dilakukan secara daring memiliki beberapa kelebihan dalam penerapannya. Pembelajaran daring membuat kegiatan belajar mengajar menjadi dapat dijangkau dari berbagai waktu dan tempat (Noermanzah \& Suryadi, 2020). Penggunaan media daring juga memungkinkan siswa untuk mendapatkan informasi yang lebih luas melalui internet. Pembelajaran daring berbeda dengan tatap muka yang terjadi di kampus atau pembelajaran konvensional. Dosen dan mahasiswa tidak dapat lagi secara langsung saling berhadapan, melainkan dengan pembelajaran 
jarak jauh yang dibantu dengan sebuah media yang memungkinkan terjadinya proses pembelajaran antara dosen dan mahasiswa.

Perkuliahan daring merupakan sarana utama dalam pembelajaran ketika wabah Pandemi Covid-19 (Widiyono, 2020). Dengan adanya pandemi ini, menjadi sangat sulit untuk mempertahankan kebiasaan gaya komunikasi pembelajaran konvensional atau tatap muka. Oleh karena itu, harus ada perubahan gaya komunikasi dosen selama pembelajaran daring ini. Tentu saja komunikasi yang dipakai adalah komunikasi yang bersifat jarak jauh. Pembelajaran daring memungkinkan mahasiswa memiliki keleluasaan waktu belajar sehingga dapat belajar kapanpun dan di manapun dengan menggunakan teknologi e-learning.

Dengan perkembangan teknologi e-learning saat ini sudah tersedia sistem pembelajaran berbasis mobile learning yang mampu mengatasi jembatan kesulitan pembelajaran bahasa mandarin (Hari dkk., 2015). Teknologi mobile learning saat ini seperti smartphone sangat menunjang untuk memenuhi kebutuhan tersebut. Mobile Learning (mlearning) merupakan teknologi mobile yang memberikan keleluasaan untuk mengakses informasi yang dapat mendukung dalam pembelajaran bahasa mandarin. Mlearning mampu menyajikan materi secara interaktif baik berupa teks, gambar, suara, animasi dan simulasi. (Darmanto dkk., 2015).

Di masa pandemi Covid-19 ini pembelajaran daring yang dilakukan oleh dosen native diberi kebebasan untuk membuat kesepakatan dengan mahasiswa dalam penggunaan platform atau aplikasi pembelajaran agar proses pembelajaran jarak jauh dapat berjalan dengan baik sehingga capaian dan tujuan perkuliahan dapat terpenuhi. Pembelajaran daring oleh dosen native dilakukan di Tiongkok, ini dikarenakan pada saat awal pandemi, semua dosen native ditarik kembali ke negaranya, yang mengakibatkan pembelajaran harus dilakukan dengan jarak jauh atau daring. Setiap dosen dapat berkreasi dan berinovasi dalam merencanakan dan menyusun model pembelajaran. Keberhasilan pembelajaran daring sangat ditentukan oleh kemandirian belajar. Kemandirian belajar dipengaruhi oleh beberapa faktor, salah satunya motivasi berprestasi (Fitriani dkk., 2020). Dengan menerapkan strategi pembelajaran daring maka kemampuan literasi digital mutlak 
dibutuhkan para mahasiswa. Hal ini karena mustahil menerapkan pembelajaran daring tanpa ditunjang literasi digital yang tinggi (Nahdi \& Jatisunda, 2020). Teknologi jaringan dan teknologi informasi untuk pengembangan sistem pembelajaran saat ini adalah sistem kuliah daring (Mustofa dkk., 2019).

Pembelajaran daring bukan hanya berbicara tentang penggunakan aplikasi daring dengan internet. Untuk penerapannya maka diperlukan pembelajaran yang bervariasi dan inovatif supaya peserta didik tetap bersemangat dalam belajar walaupun dilakukan secara daring (Firyal, 2020). Pembelajaran daring juga dikenal dengan pembelajaran online atau e-learning sebagai hasil dari suatu pembelajaran yang disampaikan secara elektronik dengan menggunakan komputer dan media berbasis komputer (Kurniawan dkk., 2020).

Kegiatan pembelajaran daring memerlukan keaktifan belajar, partisipasi, dan komunikasi interaktif antara guru dan siswa (Nurhayati, 2020). Dengan keadaan seperti ini, maka dibutuhkan strategi pembelajaran yang efektif untuk mencapai tujuan pembelajaran tersebut. Pembelajaran merupakan hal yang utama dalam sebuah institusi pendidikan, sehingga proses pembelajaran yang baik akan menghasilkan lulusan yang baik pula. Keadaan ini tentu saja perlu diperbaiki dengan meningkatkan sarana pembelajaran untuk meningkatkan proses pembelajaran secara daring dapat mendukung dan meningkatkan proses pembelajaran (Usman, 2020). Sejalan dengan kemajuan teknologi informasi dan komunikasi, kini pendekatan pembelajaran telah berubah ke arah pembelajaran abad pengetahuan. Orang dapat belajar di mana saja, kapan saja, dengan siapa saja. Itulah ciri pembelajaran abad pengetahuan yang dikenal sebagai berbasis komputer (Kuntarto, 2017).

Dalam proses pembelajaran daring, platform yang disarankan oleh universitas di Indonesia khususnya Universitas Tanjungpura adalah menggunakan platform E-Learning, Google Meet, Google Classroom, Whatsapp, atau Zoom. Hampir semua aplikasi yang digunakan di Indonesia untuk kegiatan pembelajaran daring ini tidak dapat digunakan di negara Tiongkok, karena ada kebijakan pemerintah setempat tentang penyediaan aplikasi sosial media. Dosen native diberikan kebebasan dalam penggunaan platform pengajaran online. Platform 
yang digunakan adalah DingTalk atau Tencent/VooV Meeting. Aplikasi DingTalk merupakan sekumpulan platform sistem pesan instan yang dikembangkan oleh Alibaba Group. Sistem komunikasi kolaborasi yang aman dan independen yang mengintegrasikan pesan, sms, email, suara, dan video. Apabila mereka ingin menggunakan paltform yang disarankan oleh universitas, maka dosen native harus menggunakan Virtual Private Network (VPN) untuk masuk ke aplikasi pembelajaran daring yang dapat digunakan di Indonesia.

Penelitian ini bertujuan untuk mengetahui proses pembelajaran daring yang dilakukan oleh dosen native di Tiongkok dengan mahasiswa Program Studi pendidikan Bahasa Mandarin Universitas Tanjungpura, dan untuk mengetahui kendala atau masalah yang dihadapi mahasiswa dalam pembelajaran daring serta strategi apa saja yang dilakukan oleh mahasiwa maupun dosen selama pembelajaran daring berlangsung. Harapannya dapat menjadi pengetahuan baru tentang pembelajaran daring yang digunakan di masa Covid-19 dan menjadi bahan perbaikan bagi dosen dan program studi dalam menerapkan pembelajaran daring.

\section{B. Metode Penelitian}

Metode penelitian yang digunakan yaitu metode campuran. Metode campuran atau mixed methods mengkombinasikan data kualitatif dan data kuantitatif sehingga diharapkan dapat mendeskripsikan proses pembelajaran daring, masalah-masalah dalam pembelajaran daring, dan strategi pembelajaran daring yang diterapkan pada Mata Kuliah Bahasa Mandarin Komprehensif, Program Studi Pendidikan Bahasa Mandarin, Fakultas Keguruan dan IImu Pendidikan, Universitas Tanjungpura.

Teknik pengumpulan data dilakukan dengan menggunakan teknik pengamatan atau observasi, angket/kuiesioner, dan wawancara. Pengamatan dilakukan dengan memperhatikan pola perilaku mahasiswa saat melaksanakan pembelajaran daring. Data yang didokumentasikan adalah proses pembelajaran daring mahasiswa dengan dosen native. Wawancara dilakukan dengan dosen 
navite yang digunakan untuk mengetahui strategi serta kendala yang dihadapi selama pembelajaran daring.

Angket yang digunakan dalam penelitian ini diberikan kepada mahasiswa Prodi Pendidikan Bahasa mandarin Universitas Tanjungpura sebagai subyek penelitian untuk memperoleh data efektivitas proses pembelajaran daring mahasiswa dengan dosen native di Tiongkok. Dalam penelitian ini, kuesioner bersifat tertutup. Jawaban dari pertanyaan atau pernyataan yang ada dalam kuesioner sudah tersedia, responden memilih jawaban yang telah disediakan sesuai dengan kondisi mereka masing-masing.

Teknik analisis data dengan cara menganalisis data kualitatif yaitu data hasil pengamatan dan wawancara, menganalisis data kuantitatif yaitu data kuesioner, dan menginterpretasi kedua hasil analisis dari data kualitatif dan kuantitatif sesuai rumusan masalah penelitian. Uji kebasahan data menggunakan triangulasi sumber data yang bersumber dari data pengamatan, wawancara, dan kuesioner.

Responden dalam penelitian ini adalah mahasiswa Fakultas Keguruan dan IImu Pendidikan Universitas Tanjungpura pada Program Studi Pendidikan Bahasa Mandarin. Adapun jumlah responden sebanyak 90 orang dengan data sebaran respondennya adalah sebagai berikut.

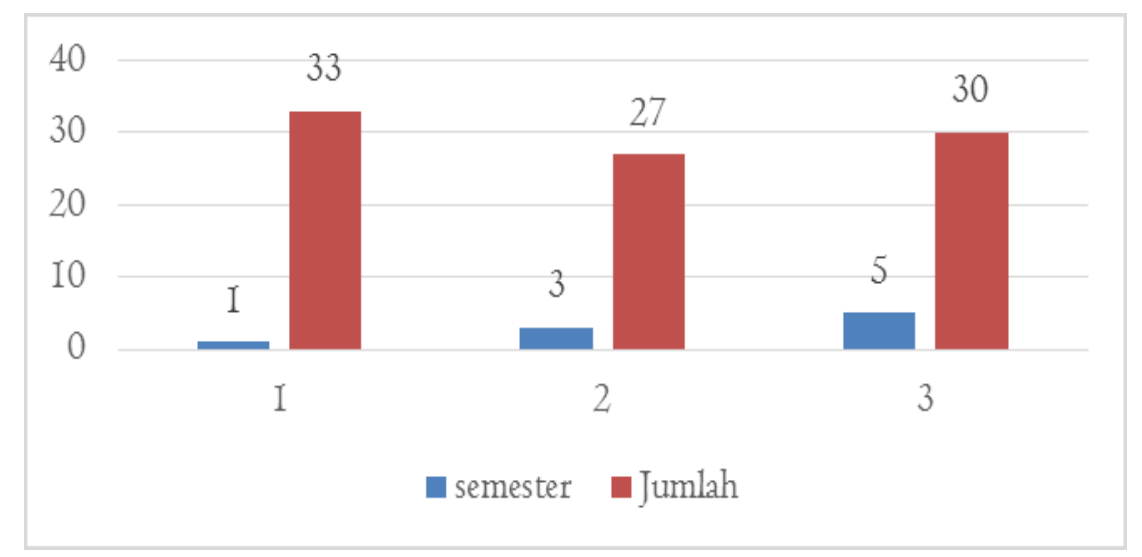

Gambar 1. Jumlah Responden

Berdasarkan tabel di atas diketahui jumlah mahasiswa yang mengisi kuesioner dan memberikan tanggapan adalah mahasiswa semester 1 sebanyak 33 responden, semester 3 sebanyak 27 responden dan semester 5 sebanyak 30 responden. 


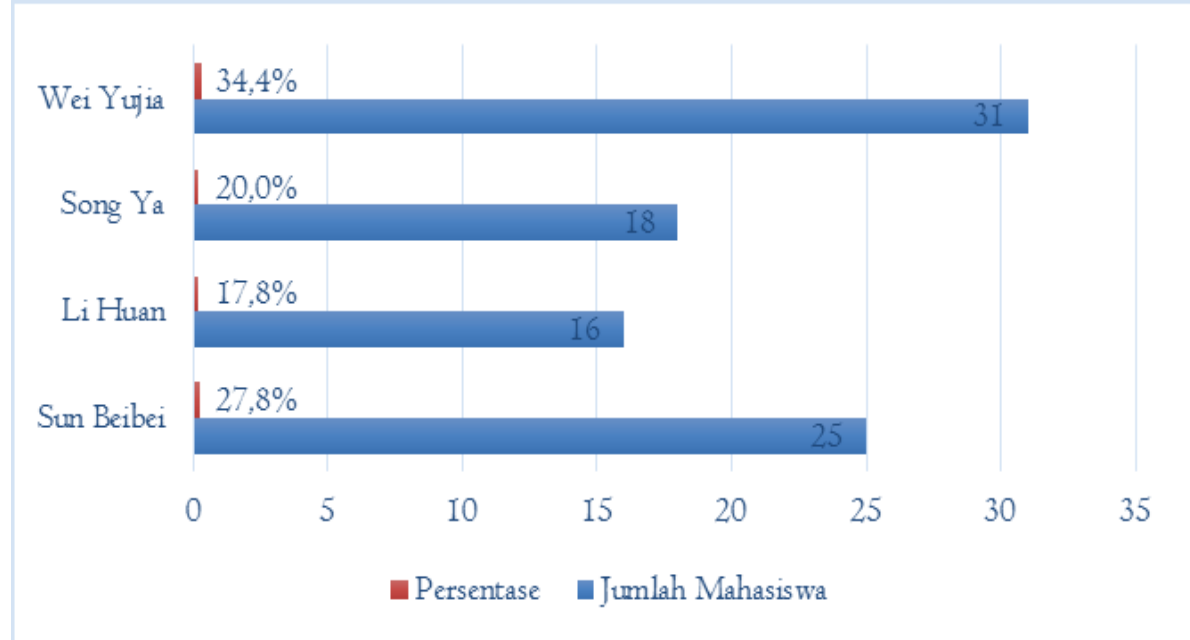

Gambar 2. Jumlah Mahasiswa Per Dosen

Berdasarkan tabel di atas dapat diketahui jumlah mahasiswa yang mengikuti mata kuliah yang diasuh oleh dosen native yaitu Mata Kuliah Bahasa Mandarin Komprehensif yaitu dosen Wei Yujia ada 31 mahasiswa $(34,4 \%)$, dosen Song Ya ada 18 mahasiswa (20\%), dosen Li Huan ada 16 mahasiswa (17.8\%) dan dosen Sun Beibei ada 25 mahasiswa $(27,8 \%)$.

\section{Hasil Penelitian dan Pembahasan}

\section{Hasil Penelitian}

a. Proses Pembelajaran Daring

Proses pembelajaran daring yang diterapkan pada Mata Kuliah Bahasa Mandarin Komprehensif menunjukkan bahwa dosen native sebagian besar menggunakan aplikasi DingTalk dan Tencent (VooV) Meeting. Media pembelajaran yang digunakan seperti komputer, laptop, maupun smartphone serta jaringan internet telah tersedia, namun tidak sepenuhnya digunakan dengan maksimal pada proses pembelajaran daring.

Ketersediaan sarana yang digunakan mahasiswa untuk mengikuti pembelajaran daring hampir seluruhnya ada. Namun, ketersediaan sarana yang ada tidak sepenuhnya digunakan dengan baik seperti ketersediaan fasilitas jaringan listrik maupun jaringan internet. Terdapat 50 (55,6\%) mahasiswa yang terjangkau oleh internet dan dimanfaatkan dengan baik, namun ada sebanyak 39 $(43,3 \%)$ mahasiswa yang tidak memanfaatkan jaringan internet yang tersedia 
dengan kata lain tidak memasang internet berlangganan di rumah. Serta ada 1 $(1,1 \%)$ mahasiswa yang di daerah tinggalnya belum terjangkau oleh internet. Ketersediaan internet tentu saja harus didukung dengan ketersediaan perangkat keras yang digunakan untuk mendukung pembelajaran daring ini seperti ketersediaan laptop, personal komputer, tablet, dan Smartphone. Pada penelitian yang dilakukan masih terdapat sebanyak $6(6,7 \%)$ mahasiswa yang tidak memiliki laptop maupun komputer untuk mengikuti pembelajaran daring. Untuk mengatasi permasalahan ketidak punyaan perangkat laptop maupun komputer masih dapat digantikan dengan Smartphone untuk menggikuti proses pembelajaran daring ini.

Dari 90 mahasiswa menunjukkan bahwa proses pembelajaran daring dalam proses pemahaman materi pembelajaran yang di sampaikan hampir sepenuhnya dapat di terima atau dipahami oleh mahasiswa dimana data penelitian menunjukkan sebanyak 86 (95,6\%) mahasiswa setuju kalau penyampaian materi oleh dosen native dapat diterima atau dipahami. Begitu juga pada sumber belajar selama proses pembelajaran daring ini juga mendapat respon positif dari mahasiswa dimana ada sebanyak $75(83,3 \%)$ mahasiswa setuju kalau dalam proses pembelajaran daring ini, sumber pembelajaran cukup mudah untuk didapatkan. Namun dari segi ketertarikkan atau pembelajaran yang menyenangkan, menurut mahasiswa pembelajaran daring kurang menyenangkan dibandingkan pembelajaran tatap muka dimana ada sebanyak $50 \quad(55,6 \%)$ mahasiswa yang kurang setuju mengatakan pembelajaran daring ini menyenangkan. Kemudian, dapat diketahui juga bahwa ada hampir sebagain mahasiswa yaitu sebesar $36(40 \%)$ mahasiswa tidak dapat berkonsentrasi secara penuh pada saat pembelajaran.

\section{b. Kendala Pembelajaran Daring}

Kendala yang dihadapi dosen native selama pembelajaran daring pada pada Mata Kuliah Bahasa Mandarin Komprehensif adalah masalah jaringan yang digunakan oleh mahasiswa yang tidak stabil, tugas terlalu banyak, sulit fokus, pulsa kuota terbatas, aplikasi yang rumit, dan mahasiswa lebih senang dengan pembelajaran tatap muka. Jaringan yang digunakan oleh mahasiswa untuk mengikuti pembelajaran daring sangat tidak stabil, mengakibatkan mahasiswa 
sering keluar masuk dalam menggunakan aplikasi DingTalk dan Tencent (VooV) Meeting.

C. Strategi Pembelajaran Daring

Strategi pembelajaran daring yang dilakukan oleh dosen native pada pada Mata Kuliah Bahasa Mandarin Komprehensif lebih sering menggunakan strategi tanya jawab untuk mendapatkan timbal-balik dari mahasiswa ketika pembelajaran menggunakan aplikasi DingTalk dan Tencent (VooV) Meeting. Selain itu, strategi yang digunakan oleh beberapa dosen dengan menggunakan waktu luang untuk membimbing secara tersendiri mahasiswa yang dianggap kurang dalam pembelajaran.

\section{Pembahasan}

a. Proses Pembelajaran Daring

Proses pembelajaran daring yang diterapkan pada Mata Kuliah Bahasa Mandarin Komprehensif menunjukkan bahwa dosen native sebagian besar menggunakan aplikasi DingTalk dan Tencent (VooV) Meeting. Dari kedua aplikasi ini didukung oleh media pembelajaran. Media pembelajaran daring dapat diartikan sebagai media yang dilengkapi dengan alat pengontrol yang dapat dioperasikan oleh pengguna (user), sehingga pengguna dapat mengendalikan dan mengakses apa yang menjadi kebutuhan pengguna (Arnesti \& Hamid, 2015). Media pembelajaran yang inovatif dapat membuat mahasiswa termotivasi dalam pembelajaran bahasa. Pembelajaran bahasa mencakup aspek keterampilan menyimak, berbicara, membaca, dan menulis (Oktavia \& Hulu, 2019). Keempat aspek keterampilan berbahasa tersebut terdapat pada Mata Kuliah Bahasa Mandarin Komprehensif. Pembelajaran jarak jauh pada masa pandemi Covid-19 ini sarana dan prasarana menjadi hal yang utama pada pembelajaran daring di seluruh universitas. Selain itu, sarana pendukung pembelajaran daring lainnya adalah aplikasi daring yang dapat diakses menggunakan media personal komputer dan telepon pintar yang terhubung dengan jaringan internet. Jaringan internet dapat digunakan jika pengajar dan pembelajar memiliki kuota internet di ponsel pintar atau memanfaatkan wi-fi. 
Tabel 1. Ketersediaan Media dan Fasilitas Pembelajaran Daring Mahasiswa

\begin{tabular}{|c|c|c|c|c|c|c|}
\hline \multirow[t]{2}{*}{ Uraian } & \multicolumn{2}{|c|}{$\begin{array}{c}\text { Tersedia dan Bisa } \\
\text { Digunakan dengan Baik }\end{array}$} & \multicolumn{2}{|c|}{$\begin{array}{c}\text { Tersedia dan Tidak } \\
\text { Bisa Digunakan } \\
\text { dengan Baik }\end{array}$} & \multicolumn{2}{|c|}{ Tidak Tersedia } \\
\hline & $\begin{array}{c}\text { Jumlah } \\
\text { Mahasiswa }\end{array}$ & Persentasi & $\begin{array}{c}\text { Jumlah } \\
\text { Mahasiswa }\end{array}$ & Persentasi & $\begin{array}{c}\text { Jumlah } \\
\text { Mahasiswa }\end{array}$ & Persentasi \\
\hline $\begin{array}{l}\text { Ketersediaan dan } \\
\text { kondisi fasilitas } \\
\text { internet } \\
\text { pembelajarjan } \\
\text { daring yang kamu } \\
\text { miliki }\end{array}$ & 50 & $55,6 \%$ & 39 & $43,3 \%$ & 1 & $1,1 \%$ \\
\hline $\begin{array}{l}\text { Ketersediaan dan } \\
\text { kondisi fasilitas listrik } \\
\text { pembelajaran daring } \\
\text { yang kamu miliki }\end{array}$ & 80 & $88,8 \%$ & 10 & $11.2 \%$ & 0 & 0 \\
\hline $\begin{array}{l}\text { Ketersediaan dan } \\
\text { kondisi fasilitas } \\
\text { (laptop/komputer/ } \\
\text { tablet) pembelajaran } \\
\text { daring yang kamu } \\
\text { miliki }\end{array}$ & 54 & $60 \%$ & 30 & $33,3 \%$ & 6 & $6,7 \%$ \\
\hline $\begin{array}{l}\text { Ketersediaan dan } \\
\text { kondisi fasilitas } \\
\text { (Hp/Smartphone) } \\
\text { pembelajaran daring } \\
\text { yang kamu miliki }\end{array}$ & 68 & $76,4 \%$ & 22 & $23,6 \%$ & 0 & 0 \\
\hline
\end{tabular}

Berdasarkan hasil penelitian yang dilakukan didapatkan bahwa ketersediaan sarana yang digunakan mahasiswa untuk mengikuti pembelajaran daring hampir seluruhnya ada. Namun, ketersediaan sarana yang ada tidak sepenuhnya digunakan dengan baik seperti ketersediaan fasilitas jaringan listrik maupun jaringan internet. Terdapat $50(55,6 \%)$ mahasiswa yang terjangkau oleh internet dan dimanfaatkan dengan baik, namun ada sebanyak 39 (43,3\%) mahasiswa yang tidak memanfaatkan jaringan internet yang tersedia dengan kata lain tidak memasang internet berlangganan dirumah. Serta ada $1(1,1 \%)$ mahasiswa yang di daerah tinggalnya belum terjangkau oleh internet. Ketersediaan internet tentu saja harus didukung dengan ketersediaan perangkat keras yang digunakan untuk mendukung pembelajaran daring ini seperti ketersediaan laptop, personal komputer, tablet, dan Smartphone. Pada penelitian yang dilakukan masih terdapat sebanyak $6(6,7 \%)$ mahasiswa yang tidak memiliki laptop maupun komputer untuk mengikuti pembelajaran daring. Untuk mengatasi permasalahan ketidakpunyaan 
perangkat laptop maupun komputer masih dapat digantikan dengan Smartphone untuk menggikuti proses pembelajaran daring ini.

Dikarenakan kebijakan kedua negara yang berbeda sehingga penggunaan aplikasi yang digunakan juga mengalami perbedaan. Pendidikan di Indonesia hampir semua aplikasi daring dapat digunakan seperti WhatsApp, Zoom, GoogleMeet, Skype, dan Google Classroom termasuk aplikasi yang digunakan oleh dosen Tiongkok yang mengajar daring dari negaranya seperti DingTalk, Tencent Meeting, namun yang menjadi salah satu kendala adalah di negara Tiongkok selain DingTalk dan Tencent Meeting tidak dapat menggunakan aplikasiaplikasi yang biasa digunakan di Indonesia.

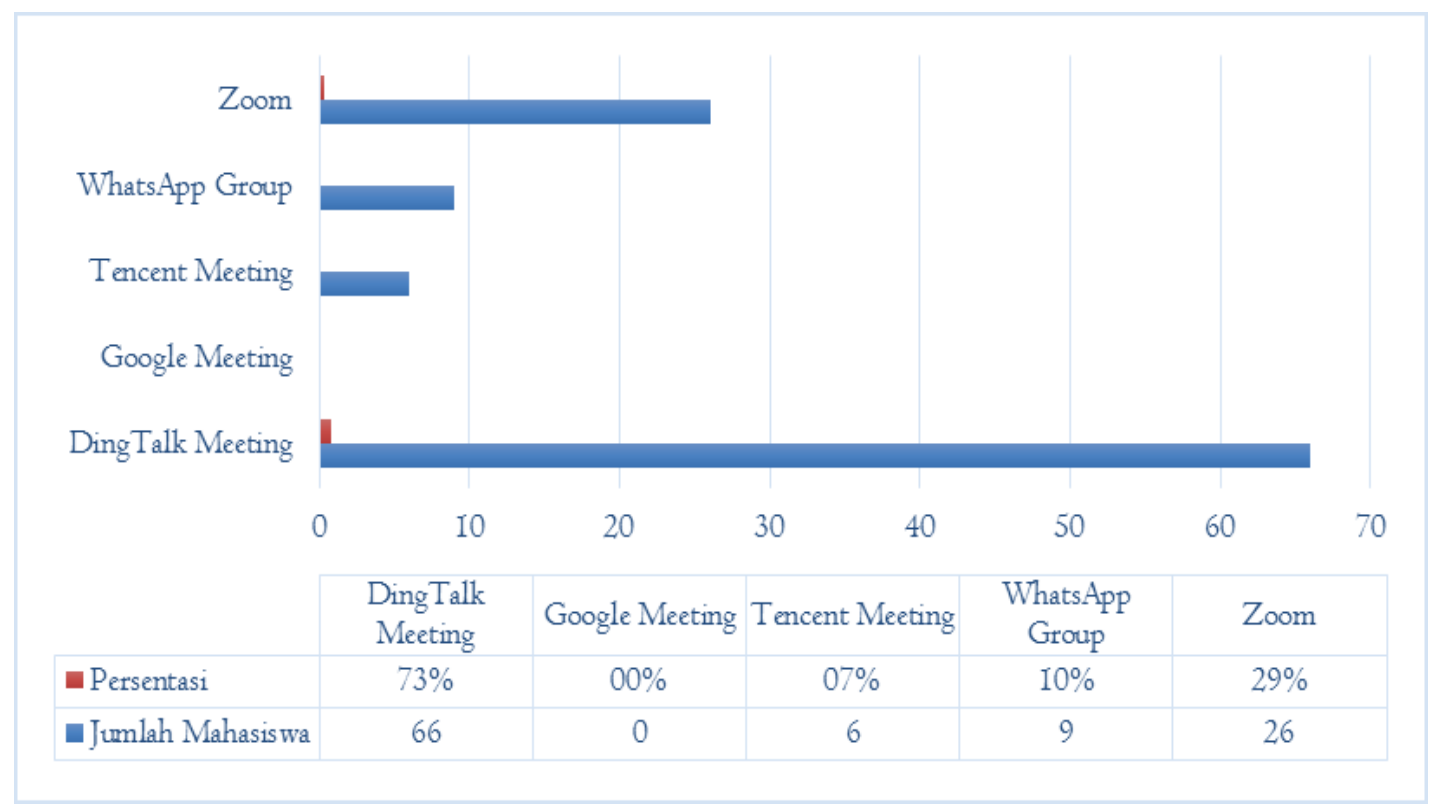

Gambar 3. Penggunakan Aplikasi Daring oleh Dosen Native

Dari tabel di atas dapat diketahui hasil penelitian mengenai penggunaan aplikasi daring yang paling sering digunakan oleh dosen native adalah DingTalk Meeting yaitu sebesar $73,3 \%$. Hal ini dikarenakan aplikasi ini yang cukup lancar dan umum digunakan di Tiongkok, sedangkan mahasiswa yang mengikuti daring dosen native harus ikut menggunakan aplikasi DingTalk Metting ini. Hal ini juga dikarenakan di Tiongkok tidak dapat mengakses Google, sehingga banyak aplikasi tidak dapat digunakan secara leluasa di sana seperti Google Meet yang sama sekali tidak dapat digunakan. Namun, ada juga dosen native yang dapat menggikuti penggunaan aplikasi yang sering dipakai di Indonesia yaitu aplikasi 
Zoom dimana penggunaannya dengan cara mengaktifkan Virtual Private Network atau sering disebut VPN.

Proses pembelajaran daring sudah berjalan sejak bulan Maret 2020, namun dari beberapa aplikasi pembelajaran daring yang digunakan, mahasiswa Program Studi Pendidikan Bahasa Mandarin merasa media pembelajaran yang digunakan tidak sepenuhnya efektif.

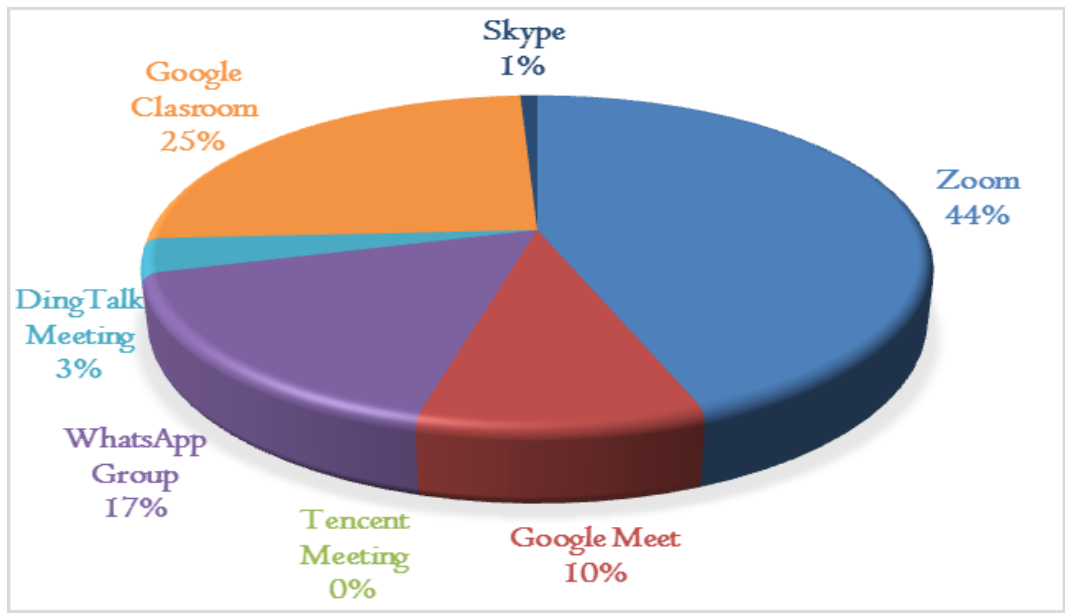

Gambar 4. Media Pembelajaran yang Dianggap Efektif

Dari diagram di atas dapat diketahui media pembelajaran yang digunakan tidak seluruhnya efektif menurut mahasiswa. Berdasarkan penelitian, aplikasi Zoom yang dianggap paling efektif yaitu sebesar 44\%, Zoom dianggap efektif karena fitur-fitur yang familiar. Aplikasi Zoom juga relatif ringan dapat digunakan di Smartphone dan Laptop milik mahasiswa. Yang terutama adalah aplikasi Zoom relatif lebih hemat kuota internet dibanding aplikasi pembelajaran daring lainnya. Sedangkan yang kedua adalah aplikasi Google Classroom sebesar 25\%. Mahasiswa merasa dengan pembelajaran online tidak harus selalu dengan video meeting, namun juga dapat dilakukan melalui Google Classroom. Google Classroom dianggap efektif karena dosen dapat mengunduh materi serta dapat menyampaikan materi secara video offline di Google Classroom ini. Untuk aplikasi meeting Tiongkok yaitu DingTalk sebesar 4\% Meeting dianggap mahasiswa kurang efektif, dikarenakan aplikasi yang tidak familiar dalam penggunaannya serta boros kuota internet. Namun aplikasi ini tetap harus digunakan karena 
menyesuaikan media pembelajaran daring dosen di Tiongkok. Sedangkan Tencent Meeting dianggap paling tidak efektif.

Tabel 2. Proses Pembelajaran Daring

\begin{tabular}{lcccc}
\hline \multirow{2}{*}{ Uraian } & \multicolumn{2}{c}{ Setuju } & \multicolumn{2}{c}{ Tidak Setuju } \\
\cline { 2 - 5 } & $\begin{array}{c}\text { Jumlah } \\
\text { Mahasiswa }\end{array}$ & Persentasi & $\begin{array}{c}\text { Jumlah } \\
\text { Mahasiswa }\end{array}$ & Persentasi \\
\hline $\begin{array}{l}\text { Mahasiswa } \\
\text { memahami materi } \\
\text { pembelajaran } \\
\text { selama proses } \\
\text { pembelajaran } \\
\text { daring }\end{array}$ & 86 & $95,6 \%$ & 4 & $4,4 \%$ \\
\hline $\begin{array}{l}\text { Mahasiswa mudah } \\
\text { mendapatkan }\end{array}$ & & & & \\
$\begin{array}{l}\text { sumber belajar } \\
\text { selama proses } \\
\text { pembelajaran } \\
\text { daring }\end{array}$ & 75 & $83,3 \%$ & 15 & $16,7 \%$ \\
\hline $\begin{array}{l}\text { Mahasiswa merasa } \\
\text { pembelajaran } \\
\text { daring itu } \\
\text { menyenangkan }\end{array}$ & 40 & & & \\
\hline $\begin{array}{l}\text { Mahasiswa tetap } \\
\text { bisa konsentrasi } \\
\text { saat pembelajaran } \\
\text { daring }\end{array}$ & 54 & $44,4 \%$ & 50 & $5,6 \%$ \\
\hline
\end{tabular}

Data hasil respons mahasiswa bisa diketahui pada tabel 4. Dari 90 mahasiswa menunjukkan bahwa proses pembelajaran daring dalam proses pemahaman materi pembelajaran yang di sampaikan hampir sepenuhnya dapat di terima atau dipahami oleh mahasiswa dimana data penelitian menunjukkan sebanyak $86(95,6 \%)$ mahasiswa setuju kalau penyampaian materi oleh dosen native dapat diterima atau dipahami. Begitu juga pada sumber belajar selama proses pembelajaran daring ini juga mendapat respon positif dari mahasiswa dimana ada sebanyak 75 (83,3\%) mahasiswa setuju kalau dalam proses pembelajaran daring ini, sumber pembelajaran cukup mudah untuk didapatkan. Namun dari segi ketertarikkan atau pembelajaran yang menyenangkan, menurut mahasiswa pembelajaran daring kurang menyenangkan dibandingkan pembelajaran tatap muka dimana ada sebanyak 50 (55,6\%) mahasiswa yang kurang setuju mengatakan pembelajaran daring ini menyenangkan. 
Dalam pembelajaran daring mahasiswa dituntut untuk lebih mandiri dalam belajar, begitu juga pada saat proses pembelajaran daring berlangsung, mahasiswa yang melakukan pembelajaran di rumah harus bisa menghadapi berbagai sistuasi dan kondisi serta lingkungan yang mungkin menggangu pada saat proses pembelajaran daring berlangsung. Sehingga didalam proses pembelajaran mahasiswa dapat lebih konsentasi serta lebih fokus dengan pembelajaran daring ini. Di dalam penelitian yang dilakukan dapat diketahui ada hampir sebagain mahasiswa yaitu sebesar 36 (40\%) mahasiswa tidak dapat berkonsentrasi secara penuh pada saat pembelajaran.

\section{b. Kendala Pembelajaran Daring}

Kendala yang dihadapi peserta didik selama pembelajaran daring, yakni jaringan internet tidak stabil, tugas terlalu banyak, sulit fokus, pulsa kuota terbatas, aplikasi yang rumit, dan lebih senang dengan pembelajaran tatap muka.

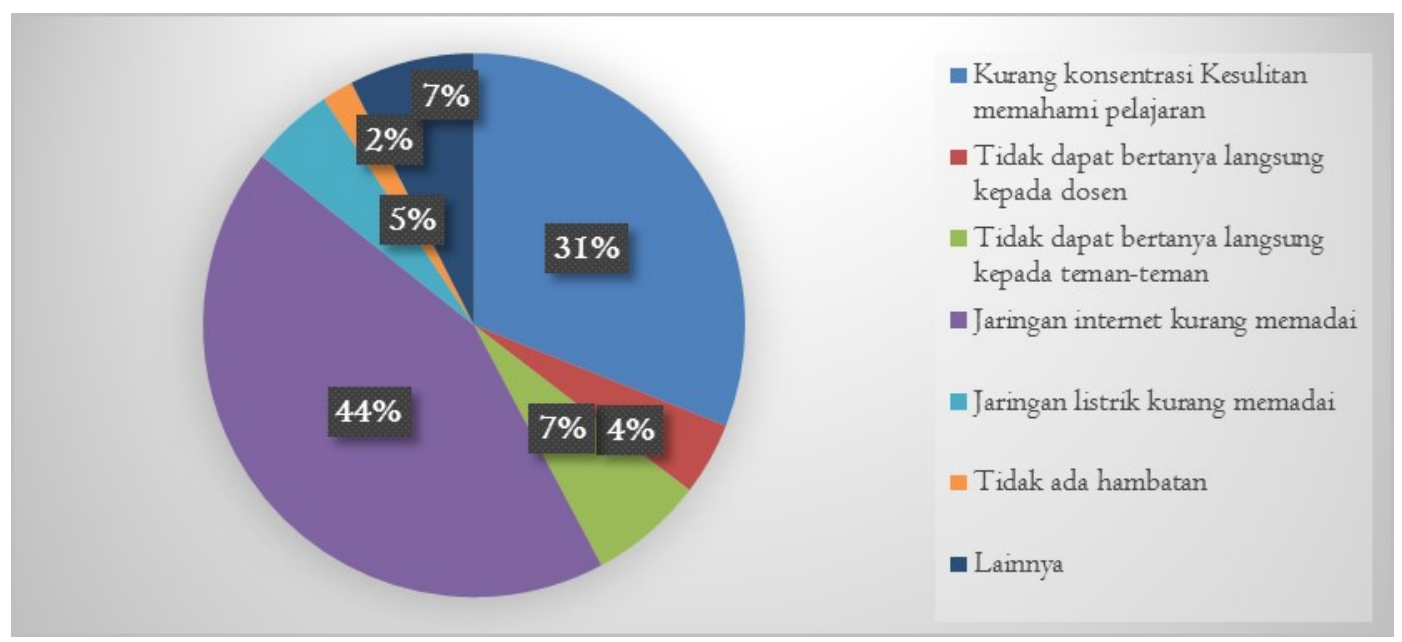

Gambar 5. Kondisi Pembelajaran Daring pada Mahasiswa

Berdasarkan gambar diagram 2, dapat diketahui kendala mahasiswa saat mengikuti perkuliahan dengan sistem daring selain jaringan internet yang kurang memadai namun di dalam proses pembelajaran mahasiswa juga mudah terganggu konsentrasi belajarnya. Berdasarkan hasil penelitian yang dilakukan ada $44 \%$ mahasiswa mengatakan jaringan internet yang digunakan untuk mengikuti pembelajaran daring ini kurang memadai. Jaringan tidak stabil juga merupakan hambatan dalam proses pembelajaran dengan sistem daring. 
Keberadaan fasilitas jaringan merupakan hal yang utama dalam pembelajaran sistem daring, karena berkaitan dengan kelancaran proses pembelajaran. Keberadaan mahasiswa yang jauh dari pusat kota ataupun jauh dari jangkauan jaringan provider tentunya tidak dapat melaksanakan proses pembelajaran dengan lancar (Iskandar dkk., 2020). Dikarenakan mahasiswa prodi pendidikan Bahasa mandarin banyak yang berasal dari daerah kecil yang dimana jangkauan jaringan internet yang terbatas. Dikarenakan adanya pandemi Covid-19 ini mengharuskan mereka untuk kembali ke daerah mereka masing-masing untuk mengikuti pembelajaran secara daring. Selain masalah jaringan internet yang susah, masalah yang sering muncul di daerah kecil adalah ketersediaan listrik yang terbatas. Listrik menjadi salah satu masalah atau hambatan dalam pembelajaran daring dimana di dalam penelitian masih ada sebanyak $5 \%$ mahasiswa yang bermasalah dengan jaringan atau ketersediaan listrik yang ada.

Di sisi lain hambatan yang dihadapi mahasiswa dalam pembelajaran daring ini adalah mahasiswa tidak dapat berkonsentrasi penuh dalam belajar, Di dalam penelitian yang dilakukan ada sebanyak 31\% mahasiswa menyatakan kurang dapat berkonsentrasi pada saat pembelajaran daring berlangsung. Hal ini disebabkan oleh beberapa faktor: 1) faktor intern, faktor intern yang mempengaruhi pembelajaran daring ini salah satunya adalah mahasiswa itu sendiri. Mahasiswa yang mengikuti pembelajaran daring dituntut untuk lebih mandiri dan harus lebih fokus dalam belajar agar semua materi yang disampaikan oleh dosen native dapat dicerna dengan baik. Namun, kenyataannya tidak demikian, mahasiswa yang belajar dirumah dikarenakan tidak dapat diawasi langsung oleh dosen, sehingga mahasiswa dapat melakukan apa saja pada saat proses pembelajaran berlangsung tanpa diketahui oleh dosen.

2) Faktor ekternal, faktor eksternal ini menunjuk pada lingkungan sekitar mahasiswa baik itu rumah maupun orang-orang sekitarnya. Apabila pada saat proses pembelajaran sebaiknya mencari tempat yang nyaman untuk mengikuti proses pembelajaran sehingga mahasiswa bisa lebih konsentrasi dan fokus dalam belajar. Pembelajaran daring tentu saja berbeda dengan pembelajaran konvensional atau pembelajaran tatap muka. Dari hasil penelitian yang juga 
menjadi salah satu masalah atau hambatan pada saat pembelajaran daring oleh mahasiswa adalah mahasiswa merasa tidak dapat berbicara ataupun mengajukan pertanyaan secara langsung apabila pada saat proses pembelajaran ditemui hal yang tidak dimengerti. Ada sebanyak 4\% mahasiswa yang mengatakan tidak dapat bertanya langsung kepada dosen dan ada sebanyak $7 \%$ mahasiswa yang menyatakan tidak dapat bertanya kepada teman-teman sejawat apabila ditemui masalah pada saat pembelajaran. Selain hambatan atau masalah yang dibahas di atas adapula masalah-masalah lainnya yang timbul pada saat proses pembelajaran daring berlangsung yaitu sebesar $2 \%$.

\section{Penerapan Strategi Pembelajaran Dosen Native}

Metode dan teknik pembelajaran harus disesuaikan dengan sarana pembelajaran. Pengajar tidak lagi dapat menggunakan metode langsung, seperti metode ceramah dalam pembelajaran bahasa yang mendapatkan dampak yang cukup berarti dengan perkembangan teknologi ini adalah bidang pendidikan, dimana pada dasarnya pendidikan sebagai proses komunikasi dan informasi dari pendidik kepada peserta didik yang berisi informasi pendidikan bersifat informatif dan efesien. Jika ingin menggunakan metode langsung seperti video konferensi dapat melalui aplikasi seperti: Zoom, Google Meet, DingTalk, Tencent, dan lainnya. Akan tetapi, hal tersebut dapat menimbulkan kendala dan memberatkan pembelajar yang berada di daerah dengan jaringan internet yang tidak lancar. Teknik diskusi juga tidak dapat dilakukan seperti diskusi pada saat pembelajaran tatap muka. Kegiatan diskusi hanya dapat dilakukan di forum-forum diskusi atau grup-grup obrolan. Diskusi yang dilakukan pada pembelajaran daring tidak dapat dilakukan secara langsung, sebab tidak semua mahasiswa dapat mengakses secara bersamaan. Kegiatan tanya jawab juga tidak akan mendapatkan umpan balik dengan cepat (Ernawati, 2020).

Seiring dengan kegiatan pembelajaran daring, dosen harus menganalisis kebutuhan dan kesulitan yang dialami oleh mahasiswa saat mengikuti kegiatan pembelajaran daring. Pada pertemuan tatap muka, tidak setiap pertemuan harus berakhir dengan tugas atau latihan. Namun pada pembelajaran daring, dengan 4 
aspek kegiatan yang salah satunya adalah latihan maka setiap pertemuan wajib ada latihan (Ernawati, 2020).

Untuk mencapai tujuan pembelajaran serta mencapai kompetensi pembelajaran yang telah disusun dosen native dituntut untuk mencari solusi untuk memecahkan masalah atau kendala yang dihadapi dalam pembelajaran daring, karena akan melakukan pengajaran terhadap mahasiswa di negara yang berbeda. Berdasarkan hasil penelitian yang dilakukan, masalah yang dihadapi oleh seluruh dosen native pada saat pengajaran daring adalah manajemen kelas, karena tidak dapat melihat langsung apa yang dilakukan mahasiswa pada saat proses pembelajaran berlangsung, sehingga mengalami kesulitan untuk melihat keseriusan serta konsentrasi belajar mahasiswa. Namun kendala terbesar yang dirasakan oleh dosen native adalah jaringan yang tidak stabil, khususnya jaringan internet pada mahasiswa. Ketersediaan jaringan internet mahasiswa di setiap tempat berbeda-beda, dikarenakan provider yang menyediakan layanan internet belum tentu terjangkau oleh mahasiswa sehingga mempengaruhi mahasiswa sering terputus koneksi internetnya. Dengan terputusnya koneksi internet secara otomatis mempengaruhi proses pembelajaran daring (video conference) yang sedang berlangsung.

Dari berbagai masalah atau kendala yang dihadapi dosen native saat proses pembelajaran daring berlangsung, maka dosen native menerapkan cara tanya jawab untuk mengetahui mahasiswa masih dalam jaringan dan masih mengikuti pembelajaran. Dosen native juga sering menujuk mahasiswa untuk menjawab pertanyaan dengan tujuan mendapatkan timbal balik, yang juga berguna untuk mengecek keberadaan mahasiswa apakah mahasiswa yang bersangkutan masih serius mengikuti pembelajaran. Dalam menghadapai mahasiswa yang kurang dalam arti tidak mengerti atau tidak memahami secara penuh materi yang sudah disampaikan. Maka dosen native akan memberi tambahan pembelajaran secara tersendiri dan secara online. Cara ini diambil langkah untuk membimbing mahasiswa yang kurang aktif dan kurang mampu dalam pembelajaran untuk dapat mengerti seperti teman-teman lainnya pada saat pembelajaran daring. 


\section{Simpulan dan Saran}

Pembelajaran daring yang diterapkan oleh dosen native Tiongkok pada Mata Kuliah Bahasa Mandarin Komprehensif, Program Studi Pendidikan Bahasa Mandarin, Fakultas Keguruan dan IImu Pendidikan, Universitas Tanjungpura menggunakan aplikasi daring yang berbeda yaitu aplikasi DingTalk dan Tencent (VooV) Meeting. Meskipun aplikasi yang digunakan berbeda, tetapi fungsinya hampir sama dengan platform pembelajaran daring di Indonesia. Mahasiswa kadang terkendala dengan penggunaan aplikasi ini, karna platform pembelajaran yang digunakan dalam bahasa Mandarin.

Masalah utama yang dihadapi dosen pada pembelajaran daring ini adalah jaringan internet yang tidak stabil pada mahasiswa. Dimana, pada saat pembelajaran daring berlangsung mahasiswa sering keluar secara otomatis dari platform pembelajaran. Selain itu, mahasiswa seringkali tidak dapat mendengar dengan jelas materi yang disampaikan oleh dosen native, mengakibatkan mahasiswa sulit untuk memahami materi yang disampaikan, serta berkurangnya komunikasi antara dosen dan mahasiswa. Hal positif yang dirasakan oleh dosen native, walapupun dosen sudah pulang ke negaranya mereka masih tetap dapat melakukan pembelajaran bahasa Mandarin kepada mahasiswa di Indonesia.

Kemudian, strategi pembelajaran daring yang dilakukan oleh dosen native lebih sering menggunakan strategi tanya jawab untuk mendapatkan timbal-balik dari mahasiswa ketika pembelajaran menggunakan aplikasi DingTalk dan Tencent (VooV) Meeting. Selain itu, strategi yang digunakan oleh beberapa dosen dengan menggunakan waktu luang untuk membimbing secara tersendiri mahasiswa yang dianggap kurang maksimal dalam pembelajaran daring.

Dari hasil penelitian ini diharapkan kepada dosen bahasa dapat memilih aplikasi pembelajaran daring yang tepat untuk mahasiswanya. Dosen dan mahasiswa juga diharapkan memahami prosedur kerja aplikasi pembelajaran daring yang digunakan. Selain itu, dibutuhkan strategi yang tepat setelah memilih aplikasi yang digunakan sehingga tujuan pembelajaran dapat dicapai secara maksimal. 


\section{Daftar Pustaka}

Annur, M. F., \& Hermansyah, H. (2020). Analisis Kesulitan Mahasiswa Pendidikan Matematika dalam Pembelajaran Daring pada Masa Pandemi Covid-19. Paedagoria: Jurnal Kajian, Penelitian dan Pengembangan Kependidikan, 11(2), 196. https://doi.org/https://doi.org/10.31764/paedagoria.v11i2.2544

Arnesti, N., \& Hamid, A. (2015). Penggunaan Media Pembelajaran Online-Offline dan Komunikasi Interpersonal terhadap Hasil Belajar Bahasa Inggris. Jurnal Teknologi Informasi \& Komunikasi dalam Pendidikan, 2(1).

Chan, D. M., \& Rahman, I. (2019). Pengaruh Gaya Belajar terhadap Hasil Belajar: Kasus Mahasiswa Prodi Pendidikan Bahasa dan Sastra Indonesia STKIP YDB Lubuk Alung. KEMBARA: Jurnal Keilmuan Bahasa, Sastra, Dan Pengajarannya (e-Journal), 5(1), 27-39. https://doi.org/https://doi.org/10.22219/kembara.v5i1.8279

Darmanto, D., Hari, Y., \& Hermawan, B. (2015). Smartphone sebagai Media Pembelajaran Bahasa Mandarin. Prosiding Seminar Nasional Multi Disiplin IImu \& Call For Papers Unisbank.

Ernawati, Y. (2020). Problematik Pembelajaran Daring Mata Kuliah Bahasa Indonesia. Jurnal IImiah Bina Edukasi, 13(1), 01-15. https://doi.org/https://doi.org/10.33557/jedukasi.v13i1.1029

Firyal, R. A. (2020). Pembelajaran Daring dan Kebijakan New Normal Pemerintah. LawArXiv. https://doi.org/10.31228/osf.io/yt6qs

Fitriani, W., Haryanto, H., \& Atmojo, S. E. (2020). Motivasi Berprestasi dan Kemandirian Belajar Mahasiswa saat Pembelajaran Daring. Jurnal Pendidikan: Teori, Penelitian, dan Pengembangan, 5(6), 828-834. https://doi.org/https://doi.org/10.31004/obsesi.v5i1.699

Fitriyani, Y., Fauzi, I., \& Sari, M. Z. (2020). Motivasi Belajar Mahasiswa pada Pembelajaran Daring Selama Pandemik Covid-19. Jurnal Kependidikan: Jurnal Hasil Penelitian dan Kajian Kepustakaan di Bidang Pendidikan, Pengajaran dan Pembelajaran, 6(2), 165-175. https://doi.org/https://doi.org/10.33394/jk.v6i2.2654

Hari, Y., Darmanto, D., \& Hermawan, B. (2015). Kajian terhadap Technology Acceptance Model pada Sistem Mobile Learning untuk Menunjang Pembelajaran Bahasa Mandarin. Informatika, 271-278.

Iskandar, I., Masthura, S., \& Oktaviyana, C. (2020). Penerapan Sistem Pembelajaran Daring pada Mahasiswa Keperawatan Universitas Abulyatama. Jurnal Dedikasi Pendidikan, 4(2), 323-332. 
Kuntarto, E. (2017). Keefektifan Model Pembelajaran Daring dalam Perkuliahan Bahasa Indonesia di Perguruan Tinggi. Indonesian Language Education and Literature, 3(1), 99-110. https://doi.org/10.24235/ileal.v3i1.1820

Kurniawan, R. I., Nindiasari, H., \& Setiani, Y. (2020). Analisis Kemampuan Pemecahan Masalah Matematis dengan Menggunakan Pembelajaran Daring. Wilangan: Jurnal Inovasi dan Riset Pendidikan Matematika, 1(2), 37-47. https://jurnal.untirta.ac.id/index.php/wilangan/article/view/8405

Mustofa, M. I., Chodzirin, M., Sayekti, L., \& Fauzan, R. (2019). Formulasi Model Perkuliahan Daring sebagai Upaya Menekan Disparitas Kualitas Perguruan Tinggi. Walisongo Journal of Information Technology, 1(2), 151-160. https://doi.org/http://dx.doi.org/10.21580/wjit.2019.1.2.4067

Nahdi, D. S., \& Jatisunda, M. G. (2020). Amalisis Literasi Digital Calon Guru SD Dalam Pembelajaran Berbasis Virtual Classroom di Masa Pandemi COVID-19. Jurnal Cakrawala Pendas, 6(3), 116-123. https://doi.org/http://dx.doi.org/10.31949/jcp.v6i1.2133

Noermanzah, N. \& Suryadi, N. (2020). Improving Students Ability to Analyze Discourse Through the Moodle-Based Blended Learning Method. English Review: Journal of English Education, 9(1), 83. https://journal.uniku.ac.id/index.php/ERJEE/article/view/3781/0

Nurhayati, E. (2020). Meningkatkan Keaktifan Siswa dalam Pembelajaran Daring melalui Media Game Edukasi Quiziz pada Masa Pencegahan Penyebaran Covid-19. Jurnal Paedagogy, 7(3), 145-150. https://doi.org/https://doi.org/10.33394/jp.v7i3.2645

Oktavia, Y. \& Hulu, F. (2019). Pengaruh Metode Quantum Learning Berbasis Media Interaktif terhadap Prestasi Belajar Bahasa Indonesia Mahasiswa di Universitas Putera Batam. KEMBARA Journal of Scientific Language Literature and Teaching, 3(2), 255-269. https://doi.org/https://doi.org/10.22219/kembara.v3i2.5133

Peraturan Pemerintah Nomor 4 Tahun 2020 tentang Pelaksanaan Kebijakan Pendidikan dalam Masa Darurat Penyebaran Coronavirus Disease (Covid-19).

Rusdiana, A., Sulhan, M., Arifin, I. Z., \& Kamaludin, U. A. (2020). Penerapan Model POE2WE Berbasis Blended Learning Google Classroom pada Pembelajaran Masa WFH Pandemic Covid-19. http://Digilib.Uinsgd.Ac.Id/30490/.

Supriadi, N., Tazkiyah, D., \& Isro, Z. (2020). (2019). Pengajaran Menggunakan Aplikasi KAHOOT untuk Meningkatkan Motivasi Belajar Bahasa 
Mandarin Siswa di SMP Nasional 3 Bahasa Putera Harapan Purwokerto. Prosiding. Prosiding Seminar Nasional Dan Call for Papers, 9(1), 187194.

Usman, M., Mario, M., Hasbi, H., Muhammad, R., \& Genda, A. (2020). Pemanfaatan Sistem Kelola Pembelajaran (Sikola) sebagai Media Pembelajaran Daring (Online) bagi Dosen dan Mahasiswa Perguruan Tinggi di Masa Pandemi. Humanis, 19(2), 66-74. http://creativecommons.org/licenses/by-nc/4.0/

Widiyono, A. (2020). Efektifitas Perkuliahan Daring (Online) pada Mahasiswa PGSD di Saat Pandemi Covid 19. Jurnal Pendidikan, 8(2), 169-177.

Wijaya, E. M. (2018). Penerapan Metode Bermain Peran dalam Bentuk Dialog untuk Melatih Keterampilan Berbicara Bahasa Mandarin Siswa Kelas XI SMAN 2 Malang. KEMBARA Journal of Scientific Language Literature and Teaching, 3(1), 41-48. https://doi.org/https://doi.org/10.22219/kembara.v3i1.4376

Wulandari, H., \& Purwanta, E. (2020). Pencapaian Perkembangan Anak Usia Dini di Taman Kanak-Kanak Selama Pembelajaran Daring di Masa Pandemi Covid-19. Jurnal Obsesi: Jurnal Pendidikan Anak Usia Dini, 5(1), 452462. https://doi.org/https://doi.org/10.31004/obsesi.v5i1.626 